\title{
OS DILEMAS ENTRE A MEMÓRIA E A HISTÓRIA EM YA MARYAM, UM ROMANCE DE SINAN ANTOON
}

\author{
The dilemmas between memory and History in Ya Maryam, a novel by Sinan Antoon
}

\author{
Jemima de Souza Alves \\ https://orcid.org/0000-0002-8206-5136 \\ Universidade de São Paulo, Programa de Pós-Graduação Letras Estrangeiras e \\ Tradução, São Paulo, SP, Brasil. 05508-010 - dlm@usp.br
}

"Oh, Virgem Santíssima, alegre-se, eu também digo, alegre-se

Pois o teu filho ressurgiu da tumba no terceiro dia." (ANTOON, 2012)

"Olhei as folhas das duas tamareiras de casa de longe erguidas no jardim dos fundos e pareciam guardar a casa. Eu também guardo a casa e suas memórias" (ANTOON, 2012)

\begin{abstract}
Resumo: No presente ensaio, analisamos como a obra Ya Maryam 'Ave Maria', de Sinan Antoon (2012), por meio da memória de seus personagens se propõe a reconstruir fragmentos da história do Iraque e entender seus desdobramentos, os quais resultaram na desintegração país. Neste romance, o autor iraquiano e cristão tece a realidade de uma típica família bagdali e dá voz à minoria cristã, vítima do sectarismo perpetrado pela intolerância religiosa desde o regime ditatorial que se impôs no país com a ascensão de Saddam Hussein, no ano de 1979. Nesta intervenção artística, que toma forma a partir da memória de dois sujeitos que representam gerações diferentes, Antoon nos coloca no espaço ideal para que versões de uma mesma história sejam confrontadas, pois narrada sob perspectivas diferentes, torna-se um exercício valioso de reflexão sobre a política da memória e seus efeitos vertiginosos na sociedade, já que desestabiliza certezas e imagens estáveis do passado.
\end{abstract}

Palavras-chave: Literatura iraquiana. Sinan Antoon. Literatura pós-colonial.

Abstract: In this essay, we analyze how Ya Maryam 'Ave Maria' (2012), by Sinan Antoon, through the memory of his characters, proposes to reconstruct fragments of the History and understand its developments in Iraq, which resulted in the disintegration of the country. In this novel, the Iraqi Christian author weaves the reality of a typical Baghdadi family and gives voice to the Christian minority, which is a victim of the sectarianism perpetrated by religious intolerance since the dictatorial regime in the country was imposed by the rise of Saddam Hussein, in 1979. In this artistic intervention that is shaped by the memory of two subjects who represent different generations, Antoon places us in the ideal space for versions of the same story to be confronted. As narrated from different perspectives, it becomes a valuable exercise of consideration about the politics of memory and its vertiginous effects on society since it destabilizes certainties and stable images of the past.

Keywords: Iraqi Literature. Sinan Antoon. Postcolonial Literature. 


\section{Introdução}

Considerada uma literatura pertencente ao gênero pós-colonial, num tom pósmoderno, a obra Ya Maryam 'Ave Maria', de Sinan Antoon (2012), apresenta uma abordagem que, em lugar da tendência de categorizar culturas subalternas e colonizadas como meros repositórios dos valores universais, criados e estimados em um cânon ocidental de narrativas originais, se propõe a fazer uma revisão do discurso oficial e, mais do que se opor ou "discordar da história", (re)escrever a história, oferecendo lugar de fala para aqueles que foram silenciados (AL-MUSAWI, 2003).

Por meio do processo de (re)escrita da história, os regimes de descolonização foram revistos e representados de uma perspectiva diferente do discurso oficial empunhado por governos e pela mídia internacional. Pois, a despeito da conquista da independência, a descolonização mostrou-se muito mais uma "transferência de poder", em que poderes externos continuaram dominando o país por meio de um governo local constituído por uma elite nativa que ainda atendia à agenda político-econômica dos colonizadores. Dentre os países do sul sob regimes neocoloniais pertencentes ao mundo árabe, o Iraque não foge à regra ${ }^{1}$.

Neste contexto, ao refletir em seu texto uma realidade iraquiana bastante diversa da comumente apresentada pela mídia internacional, Sinan Antoon (2012) tece a realidade de uma típica família bagdali e dá voz à minoria cristã, vítima do sectarismo religioso imposto pela intolerância religiosa desde o regime ditatorial que se impôs no país com a ascensão de Saddam Hussein, no ano de 1979, até sua queda, em 2003, provocada pela ocupação americana.

Bahoora (2017) observa que, com a queda do regime do Partido Baath Árabe Socialista e a consequente diminuição na censura, muitos escritores se dedicaram a representar por meio da ficção o que foi a guerra americana no país, assim como narrar as histórias experienciadas pelos iraquianos durante anos de ditadura, guerra, ocupação e conflito civil, que foram ocultadas pelas cortinas da censura e, posteriormente, do esquecimento e apatia internacional.

Essa literatura, particularmente crítica ao Iraque pós-2003, testemunha a dissolução de um espaço nacional coerente e uma esfera pública minimamente estruturada. Há uma intervenção do texto literário neste contexto para possibilitar a representação da intensidade dos horrores da guerra e seus impactos no indivíduo, que tem sido retratado na literatura na figura da nação fragmentada.

O romance de Antoon (2012) retrata, historicamente, a pluralidade e diversidade da sociedade iraquiana, que mudou dramaticamente no contexto do pervasivo e violento

\footnotetext{
1 Criado no ano de 1920, pela Liga das Nações, foi concedido ao Reino Unido, para ser administrado pelo Mandato Britânico depois da queda do Império Otomano. Os Britânicos cuidaram, então, de colocar no trono um monarca que não passava de uma marionete. No ano de 1932, o Iraque tornou-se independente do Reino Unido, para só em 1958 destronar o monarca e passar de uma monarquia à República do Iraque. Em 1968, o partido socialista Ba 't tomou o poder, permanecendo no controle do país até 2003 , ano da queda do regime ditatorial de Saddam Hussein, sucedida da invasão pelos Estados Unidos.
} 
sectarismo imposto no Iraque depois da invasão do Estados Unidos - um sectarismo que tem definido a identidade iraquiana e ameaçado suas populações minoritárias (BAHOORA, 2017).

Nesta intervenção artística, que toma forma a partir da memória de dois sujeitos que representam gerações diferentes, Antoon nos coloca no espaço ideal para que versões de uma mesma história sejam confrontadas, pois narrada sob perspectivas diferentes, é uma tentativa profícua de entender

[...] os dilemas do presente à luz do passado. Esse passado não está previamente entendido ou delimitado, mas deve ser constantemente posto em debate; a configuração do passado depende do estabelecimento de pontos de vista, critérios de avaliação, mecanismos seletivos de memória individual e coletiva. Falar em uma política da memória envolve, nesse sentido, admitir que as imagens do passado entram em confronto entre si, de acordo com diferentes estratégias de intervenção, em favor de diversos valores sociais. (GINZBURG, 2006, p. 37).

A partir desse exercício de resgatar a memória cultural do Iraque, encoberta pelas poeiras do esquecimento, Antoon (2012), por meio de seus personagens, lembra-nos de episódios históricos ignorados por nós e, certamente, pela geração iraquiana mais jovem, tocando em questões sensíveis e muito caras para a sociedade árabe, tal qual o sectarismo étnico e religioso, desterro, discriminação, guerras, regimes ditatoriais, terrorismo e intervenções político-econômicas de potências internacionais.

O romance de Antoon (2012), nesse sentido, por meio das memórias retalhadas de Youssef e Maha, quando alinhavadas, torna-se uma tentativa de entender os processos históricos que levaram o Iraque de uma posição de país plural e tolerante ao regime ditatorial, que acaba nas mãos do Estado Islâmico.

\section{Ya Maryam (Ave Maria)}

Maha Jurji é uma jovem iraquiana cristã, de Bagdá, na altura de seus vinte anos. Estudante de medicina, tem dentro de si o mesmo sentimento que outros jovens de seu país: uma ânsia para deixar o Iraque. Assim como milhares de seus compatriotas, ela não acredita que o Iraque seja sua pátria e planeja emigrar assim que tiver em mãos seu diploma de médica: "Tudo que quero é viver em um lugar em que eu seja como os outros. Em que eu caminhe, saia e entre e ninguém aponte para mim ou me considere diferente" 23 (ANTOON, 2012, p. 111).

É digno de nota que os eventos dos últimos quase vinte anos que tiveram palco nas principais cidades Iraquianas, desde a criação do Estado Islâmico (2003/2004) e seu auge de controle, bem como o destino catastrófico de centenas de milhares de iraquianos (cristãos, yazidis, chabaks entre outras minorias) confirmam todos os temores de Maha

\footnotetext{
2 Todas as traduções do romance, em árabe, Ya Maryam (Ave Maria), 2012, são nossas.

3 (ANTOON, 2012, p. 111)$$
\text { كل ما أريده هو أن أعيش في مكان أكون فيه مثل الآخرين. أمشي وأخرج وأدخل ولا يشار إلي أو يتم تذكيري باني مختلفة. }
$$ 
sobre o fim de seus irmãos de fé, no Iraque. Ela e sua família já haviam tido uma experiência similar, décadas anteriores: intimidação, sectarismo, violência e desterro.

O estado iraquiano, que se constituiu após 2003, e suas instituições corruptas nunca funcionaram para Maha e sua família. Não havia qualquer medida protetiva ou de segurança, e a cultura e sistema de milícias significava que os grupos que não fizessem parte com uma milícia ou partidos sectários para lhes representar eram os mais vulneráveis. Esses indivíduos tornavam-se presa fácil em meio ao caos e violência desencadeados pela ocupação americana:

Antes dos americanos, sinceramente, minha situação era bem melhor. Eu ia e vinha livremente. Naquele tempo, eu podia dormir debaixo de uma árvore em qualquer canto que ninguém me agredia. Agora, é preciso dormir num hotel ou posso ser morto. Essas paredes de concreto nos sufocam. Ustadh, até as tamareiras passaram a ser sunitas e chiítas. ${ }^{4}$ (ANTOON, 2012, p. 84).

A família Jurji vivia em Al-Dorah, um distrito a sudoeste de Bagdá, onde, por décadas, iraquianos sunitas, chí́tas e cristãos viveram lado a lado. Entretanto, a guerra civil e o processo de limpeza étnica que Bagdá testemunhou, entre os anos de 2005 e 2007, transformou as regiões ecumênicas em espaços habitados por muçulmanos chítas ou sunitas. Inicialmente, os chiítas foram expulsos dali por grupos extremistas, e, no ano de 2007, foi a vez dos cristãos. Como ocorreu a diversas famílias cristãs de Al-Dorah, a família de Maha recebeu um ultimato: a conversão ao islã ou o pagamento da jizya ${ }^{5}$.

A princípio, a família não deu crédito às ameaças que lhes foram dirigidas, porém, eles passaram a receber cartas de notificação para que deixassem o bairro e, posteriormente, sua casa tornou-se alvo de tiros. Como tantos outros milhares de desterrados, tiveram que sair de casa, deixando-a aos cuidados do vizinho muçulmano, a quem a família sempre depositou grande confiança, e foram em busca de abrigo no norte do país. A população cristã de Al-Dorah foi drasticamente reduzida, e suas igrejas de variadas denominações, cujas reuniões dominicais eram repletas de pessoas, foram atacadas ou fechadas.

Após se mudarem para a região leste de Bagdá, sua família buscou refúgio, como tantos outros milhares de cristãos, em Ainkawa, onde esperavam por documentos de refúgio por perseguição religiosa, entre a população curda. Acreditando que a obtenção dos documentos de refúgio seria mais fácil com o diploma de médica, Maha decide permanecer em Bagdá junto ao tio, e, assim que possível, sair do Iraque, que não tinha lugar para ela: "Entrei no nosso quarto escuro, que não era nosso quarto propriamente, mas um ponto de parada, como é a casa inteira. Como é nossa vida nesses dias"6 (ANTOON, 2012, p. 105).

\footnotetext{
${ }^{4}$ (ANTOON, 2012, p. 84)

الاقبل الأمريكان جان وضعي أحسن بصراحة. جنت أروح واجي بكيفي. أيام زمان جنت أنام جو الثجرة بأي زاوية، محد يندك بي. هسة لازم أنام بفندق

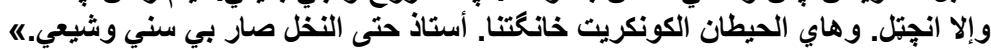

${ }^{5}$ Em árabe: جزية "jizya" é um imposto per capita pago a um estado islâmico aplicado aos não muçulmanos como demonstração de sujeição ao governo local e garantia da prática religiosa diferente do Islã. 6
}

$$
\text { لخلت غرفة نومنا المظلمة، التي لم تكن غرفتنا، بل محطة انتظار، مثل البيت كله، ومثل حياتنا هذه الأيام. }
$$


Por se sentir tão alheia à sociedade iraquiana, Maha anseia deixar o país e viver onde encontre pessoas que lhes sejam semelhantes, ou com as quais tenha afinidades culturais, ou se reconheça como parte dessa sociedade. Mas a pergunta que precisamos fazer é: será que esse lugar existe? As reflexões de Youssef contradizem essa expectativa, pois, fora do Iraque, embora se reconheça na cultura cristã, Maha se verá como estrangeira.

Enquanto na perspectiva de Youssef temos o sentimento de unidade iraquiana, apesar das diferenças étnicas e religiosas, na visão de Maha, temos a completa ignorância sobre a alteridade. O muçulmano em sua fala se mostra totalmente alheio ao cristão, muito embora vivam em um mesmo país e, de alguma forma, convivam e ocupem os mesmos espaços, haja vista o modo como Maha refere-se a um colega de universidade:

Certa feita, havia levado comigo rosquinhas de kleicha ${ }^{7}$ num saquinho para a universidade e, quando tirei uma delas para comer antes da aula um dos meus colegas, que sabia que eu era cristã, perguntou-me surpreso: 'sério que vocês comem kleicha?'. Então eu the respondi sem que pudesse esconder meu aborrecimento: 'sim, comemos kleicha e bebemos chá e água como vocês'8 (ANTOON, 2012, p. 111).

Para além do suposto desconhecimento, há ainda uma clara deturpação da imagem da alteridade: "Ouvi dizer que vocês [cristãos] na passagem de ano, à meia noite, o padre apaga a luz e diz para cada um beijar a menina que está parada ao seu lado. Isso é verdade?"9 (ANTOON, 2012, p. 112).

Sentindo-se sempre insultada por opiniões acerca dos cristãos expressadas por mulçumanos, a jovem está constantemente em conflito com a alteridade, devido às imagens que ambos os grupos criaram um do outro e aos posicionamentos políticos divergentes que sustentam, sobretudo no diz respeito à ocupação americana em solo iraquiano, em relação à qual trocam acusações sobre qual dos lados apoiou mais essa violenta intervenção:

Escrevi uma resposta [no Facebook] mencionando que os muçulmanos também trabalharam em prol da ocupação e que os políticos iraquianos que fizeram propaganda da ocupação e permitiram que os americanos viessem ao Iraque e trabalharam com a ocupação por muitos anos eram muçulmanos. [...] Não surgiu a maioria da elite política com a ocupação? E todos esses partidos religiosos e sectários, não trabalharam com a ocupação? Há quem é apoiado por Irã ou a Arábia Saudita ou a Turquia, mas quem nos apoia? ${ }^{10}$ (ANTOON, 2012, p. 112).

(ANTOON, 2012, p. 111)

${ }^{7}$ Considerada uma iguaria no Iraque e na Arábia Saudita, a kleicha é um doce à base de farinha temperada com especiarias e recheado tâmaras. Nesse romance, ele é referido pela personagem como 'ka' 'k', bolo. 8

ذات مرة كنت قلد أخذت معي كعك الكليجة في كيس صغير إلى الجامعة وعندما أخرجت واحدة لآكلها قبل المحاضرة سألني أحـ زملاثي والذي كان يعرف

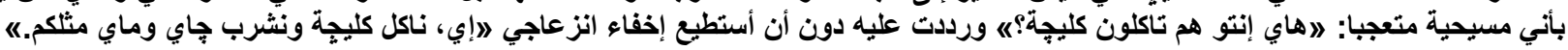
(ANTOON, 2012, p. 111)

(ANTOON, 2012, p. 112)

إنتو براس السنة من تصير ثنعش بالليل القس يطفي الضوة ويكول لكل واحد يبوس البنية اللي واقفة يمه. صدك؟ه رآني سمعت 10 
A todo momento, lembrada por seus colegas acerca de sua pertença a uma minoria, suas relações sociais eram completamente diferentes da que tinha seu tio, cujo melhor amigo era muçulmano e o tratava de igual para igual:

Cansei-me de tudo e de todos que me lembravam, fizesse sentido ou não, que eu era uma minoria. Até o crucifixo de ouro presenteado pela minha avó, na minha primeira comunhão, não usava mais no meu pescoço. [...] Passei a trazê-lo comigo na minha bolsa para me proteger, todos os dias. ${ }^{11}$ (ANTOON, 2012, p. 112).

Maha está certa de que seu tio vive, de fato, no passado, não entendendo o que realmente se passa no Iraque, pois só sai à rua para comprar o jornal e encontrar os poucos amigos que lhe restaram. Ela, por outro lado, porque está mais exposta ao convívio social, sente-se censurada por homens e mulheres.

Ele não deve imaginar os sentimentos de uma mulher sujeita a esses olhares. Olhares que eu percebo como se tirassem fotos para diagnosticar a natureza da minha doença e impureza, pois não sou como eles nem pertenço a sua religião. Esses olhares não são lançados apenas pelos homens, mas até pelas mulheres cujos olhos me percebem como se eu fosse uma prostituta porque não uso o hijab. ${ }^{12}$ (ANTOON, 2012, p. 110).

Entretanto, apesar desse sentimento de deslocamento, mesmo o refúgio em outro país não the traria a liberdade que buscava. Aonde quer que fosse seria estrangeira, seria ainda uma minoria. No Iraque, por ser cristã e, em outro país, por ser iraquiana. Maha vive o drama de ser estrangeira no seu país, assim como o seria no país do outro. Parece-nos que aquilo de que se quer se ver livre sempre a acompanhará, pelo menos até que a situação política de seu país mude. Só a mudança na concepção identitária iraquiana poderia fazer Maha encontrar no Iraque sua pátria:

Eu quero viver livremente e colocar no meu pescoço o que quiser, vestir longo ou curto. Admoestou-me Youssef, mais de uma vez, que ao emigrar e viver em outro país de maioria cristã não seria livre de problemas e dificuldades e não significaria que eu não me sentiria uma minoria lá também. Disse-me que eu sofreria preconceito porque sou árabe. [...] disseIhe que estou pronta para enfrentar qualquer coisa, desde que viva longe de

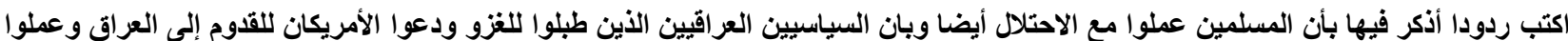

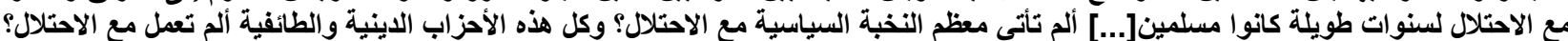

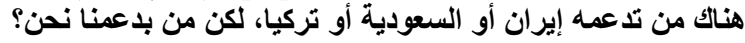
(ANTOON, 2012, p. 112)

11

تعبث لأن كل شيء وكل شخص يذكرني، بمناسبة وبدونها، بأي أقلية. حتى الصليب الذهبي الذي أهدته لي جدتي بمناسبة طقوس المناولة الأولى لم أعد (ANTOON, 2012, p. 112) 12

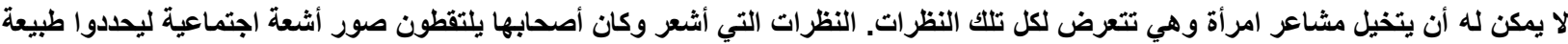

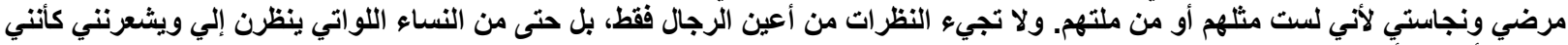
عاهرة لأنني لا أرتدي الاندي الحجاب.
}

(ANTOON, 2012, p. 110) 
bombardeios, terroristas e sectarismo. Ele murmurou: 'você é livre'. ${ }^{13}$ (ANTOON, 2012, p. 113).

Em dado momento, as coisas foram se acalmando em Bagdá e, mesmo no bairro de Al-Dura, parecia que tudo voltara ao normal. Maha se casa com um dos membros da igreja local e ambos acreditam que não há razão para não voltar a casa da família, sobretudo ao ver na televisão uma entrevista com um morador muçulmano do bairro, convocando os cristãos a retornar ao lar: "Fiquei tocada quando assisti a alguns deles falando diante das câmeras nos pedindo - nós seus irmãos cristãos, como nos chamávamos - para voltar às nossas casas porque a região estava segura agora"14 (ANTOON, 2012, p. 125-126).

Maha e o marido Lu'ay mudam-se para a casa na qual ela viveu toda sua infância, pois ainda que marcada por perdas e dores, havia ali em sua memória momentos de muita ternura e afeto: "Como me esquecerei a ausência do meu tio, Muhlis, que me paparicava como nunca ninguém mais" ${ }^{15}$ (ANTOON, 2012, p. 114).

A despeito de estar cercada de familiares que a querem muito bem e de desfrutar de alguns momentos de alegria, já na infância, começa a experienciar o sentido de palavras que crianças não deveriam saber: "Percebi, depois de um tempo, que sequestro significa que a pessoa que amamos, por causa dos maus, não voltará"16 (ANTOON, 2012, p. 114).

Para sua avó, a morte de seu filho se deu por uma única e simples razão: porque era cristão: "Quando consolada, minha avó repetia chorando que o haviam sequestrado e matado porque ele era cristão"17 (ANTOON, 2012, p. 116).

Tão inundada nesse mar de tristeza, Maha teme que, mesmo deixando o Iraque, depois de completado seus estudos, é possível que todo horror que ali viveu a acompanhe. É a memória e o medo de ser perseguida pelos fantasmas dos eventos passados: "Será que as coisas ficarão realmente 'bem' depois que eu terminar meus estudos e sair desse inferno? Ou este poço escuro e seco, a não ser das minhas lágrimas, no qual estou a cair continuamente, me perseguirá por todos os lugares?"18 (ANTOON, 2012, p. 106).

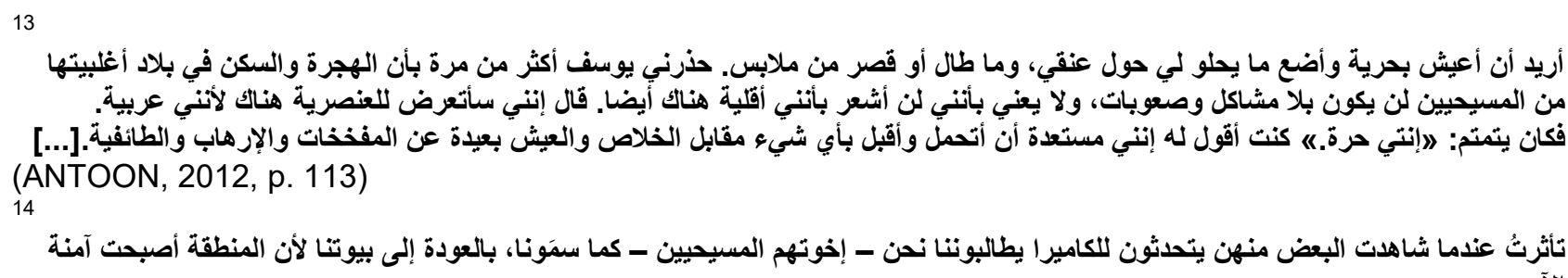
(ANTOON, 2012, p. 125-126) 15 فكيف لي أن أنسى غياب خالي، مخلص، الذي كان يدللني كما لم يدللني أحد.

(ANTOON, 2012, p. 113)

16

(ANTOON, 2012, p. 114) ] [الاختطاف يعني أن لا يعود الثخص الذي نحبه لأن الأشرار أدركت فيما بعد بأن

(ANTOON, 2012, p. 116)

لأنه مسيحي. كاتت جدتي تردد في العزاء وهي تبكي بأنهم اختطفوه وقتلوه 18 
Com a esperança de experienciar uma nova vida ao lado de seu marido, passados alguns meses do casamento, o jovem casal descobre a gravidez e, cheios de expectativa, preparam a casa para receber o pequeno Bachar. Entretanto, nos parece que o destino não Ihes dá trégua. Semanas antes de Bachar vir ao mundo, um carro bomba, parado à frente da casa da família Jurji, traz a catástrofe novamente à casa de Maha e a jovem perde o bebê, com o choque da explosão.

De todas as perdas que sofreu - o lar, o tio querido sequestrado e morto por terroristas, a infância, a vivacidade do pai -, o filho será a mais amarga das dores da qual jamais se recuperaria: "Agora acredito no que me disse minha avó quando era criança. Disse-me que a azeitona era um fruto doce, mas seu sabor ficou amargo depois daquela noite quando Jesus chorou sozinho irrigando as oliveiras com sua dor"19 (ANTOON, 2012, p. 136).

Mesmo aproximando-se da religião, e buscando refúgio na imagem da Virgem Maria que, como ela, teve um filho condenado à injusta morte, Maha vive um mar de dores:

Todos os anos o Filho de Deus ressurge da morte, mas o filho dos homens, meu filho, sucumbiu na morte antes mesmo que nascesse, e não ressurgirá de lá jamais. Tornou-se o ventre em tumba e o corpo, cemitério. Cemitério que visito sem que me mova"20 (ANTOON, 2012, p. 136).

Após deixar o hospital, Maha e o marido passam a viver em um dos pisos da casa de seu tio paterno Youssef, com o qual passa a cultivar uma relação de pai e filha, mas com quem tem sérias divergências políticas. Aos olhos da jovem, o que acontece no Iraque, assim como nos países vizinhos, é só mais um capítulo da história de violência contra as minorias, sobretudo os cristãos, nos países muçulmanos:

Não foram os assírios massacrados nesse período do reinado jubiloso? Não imigraram os judeus iraquianos quando expulsos de suas casas e de seu país no meio da noite? Não houve aumento da pobreza? E os períodos que se seguiram não estiveram cheios de massacres e valas comuns para os curdos e os chiítas? ${ }^{21}$ (ANTOON, 2012, p. 139-140).

Para ela, as raízes dessa violência sectária derivam diretamente da intolerância dos

(ANTOON, 2012, p. 106)

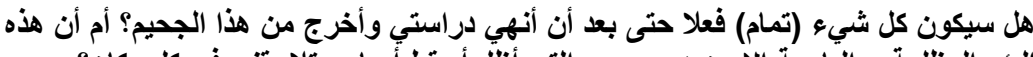
البئر المظلمة، واليابسة إلا من دموعي، والتي أظلّ أسقط أبها، ستيلاحقني في كل مكان؟ 19

أصدق الآن ما قالته لي جدتي ذات مرة عندما كنت طفلة. قالت لي إن الزيتون كان ثمرة حلوة لكن طعمه صار مر بعد تلكت الليلة التي بكى فيها المسيح وحيد وسقى أشجار الزيتون بآلامه.

(ANTOON, 2012, p. 136)

20

ابن الله كان يقوم من الموت كل عام، لكن ابن الإنسان، ابني أنا، غرق في الموت حتى قبل أن يولد، ولن يقوم مذه أبدا. فصار الرحم قبرة والجسد مقبرة.

(ANTOON, 2012, p.136)

21

ألم يذبح الآثوريون في ذاك العها الملكي السعيد؟ ألم يتم تهجير اليهود العراقيين وطردهم من بيوتهم ويلاهم الذي عاشوا فيه بين ليلة وضحاها؟ ألم

(ANTOON, 2012, p. 139-140)

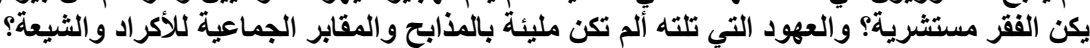


muçulmanos, pois é esse o cenário em que viveu durante toda a vida. $\mathrm{Na}$ verdade, as perdas e dores que ela traz na memória estão todas associadas a reações de intolerância religiosa.

Em contrapartida, Youssef viveu o suficiente para testemunhar uma fase da história iraquiana em que se podia gozar de certa paz e a coexistência de grupos religiosos diversos, bem como ter memórias de um Iraque mais plural e secular. Apesar de reconhecer os problemas políticos de sua época, percebe que a identidade das pessoas era definida muito mais por sua classe social, educação e ideologia do que por sua religião, haja vista que seu mais antigo amigo, Sa'dun, era muçulmano:

Sa'dun, naquele tempo, ensinava língua árabe em uma escola secundária e possuía com seu irmão uma loja de materiais de escritório, em Al-Kirada, a qual herdaram do pai. Convidou-me para integrar o 'clube Al-Khayam' e encontrá-los semanalmente. O nome do clube originava-se do bar do hotel Al-Khayam [... $]^{22}$ (ANTOON, 2012, p. 72-73).

Youssef acredita que, nos últimos tempos, poderes políticos vestem a máscara da religião e do sectarismo para fins escusos e inescrupulosos. Além disso, a despeito do que diz a versão contemporânea da história, o Islã não detém o monopólio sobre a violência e que os cristãos também foram autores de crimes cometidos em nome do Cristianismo:

'Essa religião [o islã] se espalhou pelo fio da espada. O que se espera disso?'

Então eu lhe disse: 'E o que dizer do cristianismo, como se espalhou? Com conversas, gentilezas e canções? Se não fosse esse imperador romano, que eu esqueci o nome, que se tornou cristão, não tinha se espalhado depressa. $E$ depois quem entrasse na cidade, e não se tornasse cristão perdia a cabeça, não tinha jizya nem nada. Nas cruzadas e na descoberta da América do Norte e do Sul vinte milhões foram massacrados com a benção da igreja. ${ }^{23}$ (ANTOON, 2012, p. 25).

Para ele, os conflitos desencadeados em solo iraquiano são produtos de governos ditatoriais e ocupações militares e não pura e simplesmente de textos religiosos. Sua esperança é que o país supere esse declínio histórico e recupere o patriotismo e o controle sobre sua história:

'Bem, eu não sei desses detalhes, tio. Isso aí é tudo passado. Nós temos um problema agora, no presente. Os muçulmanos não nos querem, simples

22

كان سعدون أيامها يدرس اللغة العربية في مدرسة ثانوية ويملك مع أخيه محلا لبيع القرطاسية في الكرادة كانا قد ورثاه عن أبيهما. دعاني للانضمام

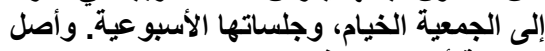
(ANTOON, 2012, p. 72-73) التسمية أن مشرب فندق الخيام كان[.... 23

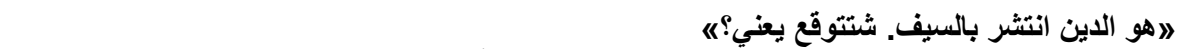

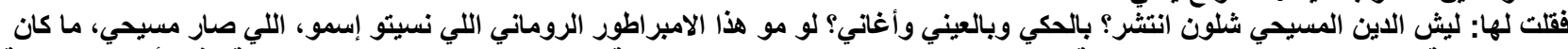

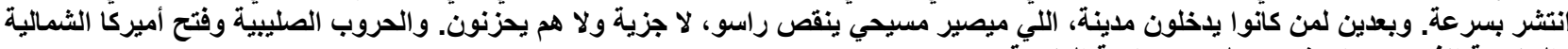

(ANTOON, 2012, p. 25) والجنوبية انذبحو بيها عشرين مليون بمباركة الكنيسة. 
assim, para que o país continue apenas deles.'

'Como deles? O país é país de todos. É nosso, dos nossos avós, e dos antepassados. A história é inabalável... desde os tempos dos Daqnawus. Desde os caldeus aos abássidas e otomanos fundou-se o país iraquiano. Os museus estão de prova. Estivemos aqui sempre, se esse país não é nosso será de quem? O que você me diz?'24 (ANTOON, 2012, p. 26).

Não obstante acredite na existência desse passado jubiloso, Youssef, que narra em primeira pessoa, - ou sua geração - não consegue encontrar um ponto na história do Iraque em que se divise seu início ou fim. Para os saudosistas, o fim do Iraque se deu em momentos históricos distintos. Atribuem justificativas diferentes para a origem da época de ouro do país:

Este passado em que tudo era belo e imaculado. Mas, estranhamente, para aquele, o início e o fim não começavam no mesmo ponto. Então, há aqueles que consideram o início do regime ba tista, em 1963, e a barbárie que matou o Abd El-Karim Qasim, o fim dos tempos ditosos. Há outros que consideram a ascensão de Saddam o início do fim. E os que estendem o tapete dos tempos ditosos até o fim de 1991, pois o embargo foi o início do fim do Iraque. Há ainda os que consideram o fim, em 2003. ${ }^{25}$ (ANTOON, 2012, p. 139).

As sequentes tragédias e conflitos que foram se sobrepondo, ao longo da história do país provocou nos indivíduos uma tensão e uma expectativa, pois já não se conseguia prever os rumos que tomaria o Iraque:

Eu me lembrei de como a guerra me aproximou dela [Maha] pela primeira vez no ano de $1991^{26}$. E como uma outra guerra, ou melhor, o que a seguiu, devastação e calamidade, fê-la mudar o rumo de sua vida para viver comigo sob o mesmo teto, ela e seu marido. Eu nunca poderia imaginar isso. Mas quem poderia imaginar alguma coisa do que ocorreu nas últimas décadas? ${ }^{27}$ (ANTOON, 2012, p. 27)

Mesmo destituído das condições mínimas de segurança para viver na casa em que construiu e viveu por longos anos com a irmã, Hinna, Youssef insiste em se manter enraizado onde guarda sua história e memória:

\section{4}

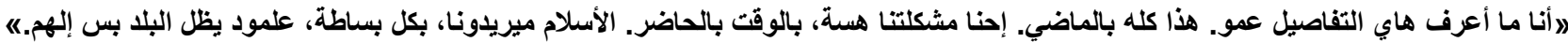

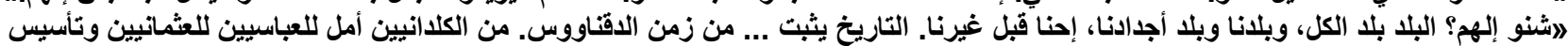
(ANTOON, 2012, p. 26)

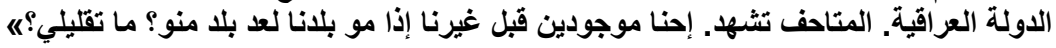

25

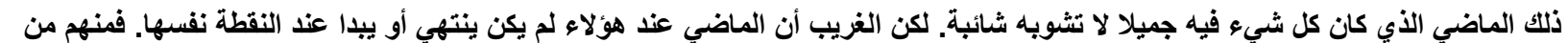

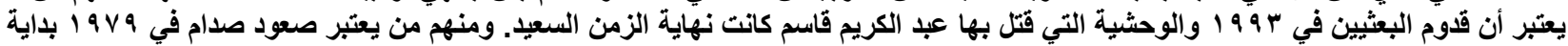

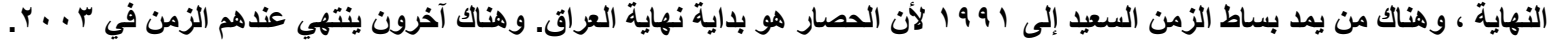
(ANTOON, 2012, p. 139)

${ }^{26}$ A guerra de 1991 a que se refere o narrador trata-se da Guerra do Golfo.

27

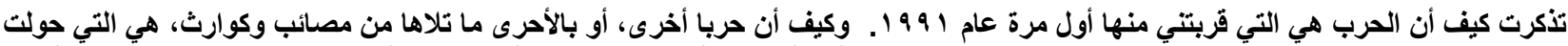

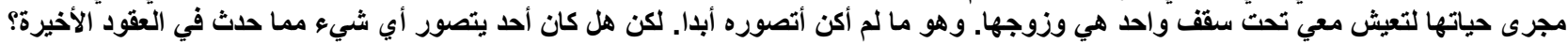
(ANTOON, 2012, p. 27) 
Eu preferi permanecer em casa, embora Hinna insistisse em juntar-se aos outros parentes, principalmente porque os bombardeios a assustava. A base do comando das forças aéreas era perto de casa, e o bombardeio acontecia 'sobre as nossas cabeças', como, depois, repetia continuamente aos outros. Quando discutimos sobre a possibilidade de irmos ao campo de refúgio, disse-lhe: 'Se Deus quiser que morramos, morreremos onde estivermos'. Então, respondeu-me: 'Morreremos onde estão nossos parentes, melhor. Por que morrermos sozinhos?'. 'Por acaso isso é uma festa? Eu quero morrer na minha casa!', repliquei. ${ }^{28}$ (ANTOON, 2012, p. 27).

Sua casa, um repositório de memórias de uma família descendente dos caldeus e que, por gerações, estava estabelecida no país dos Dois Rios, de modo que as memórias de sua família não estão reduzidas à história do Iraque recente, mas remontam a um período que antecede a presença árabe na região: "Sua mãe relativamente nova chegada do vilarejo dirigia-se aos filhos e ao marido na língua dos caldeus, que eles compreendiam, mas respondiam em árabe"29 (ANTOON, 2012, p. 42).

As fotografias de família não tinham como referência momentos ordinários, mas eram sempre rememoradas a partir de um movimento histórico:

Ninguém sabia exatamente a história daquela fotografia. Entretanto, Youssef se lembrava que fora tirada naquela sexta-feira, um mês antes do movimento de Rachid 'Ali Al-Gaylani, no ano de $1941^{30}$. Isso quer dizer que ele deveria ter uns oito anos. Fora tirada na casa antiga da família, em 'Aqd An-Nassary, que dividiam com a família do tio Yuhnna. ${ }^{31}$ (ANTOON, 2012, p. 37).

Por meio de objetos e das fotografias espalhadas pela casa, Youssef reconstrói e revisa a história todos os dias. Percebe nos detalhes comezinhos como o país, em 1950, era mais moderno e gozava de certas liberdades extirpadas da sociedade: "Ghazi vestia um terno escuro com uma gravata, ao seu lado, Samira trajava um vestido que mostrava seus ombros e braços e o decote de seus seios" (ANTOON, 2012, p. 50). Reconhece que mesmo com alguma dificuldade, no fim da década de 1970, era possível a relação matrimonial entre muçulmanos e cristãos: "Ela era mais nova que ele mais de vinte anos. Impossível que se atraísse por um homem da idade de seu pai. Como ela era muçulmana

\section{8}

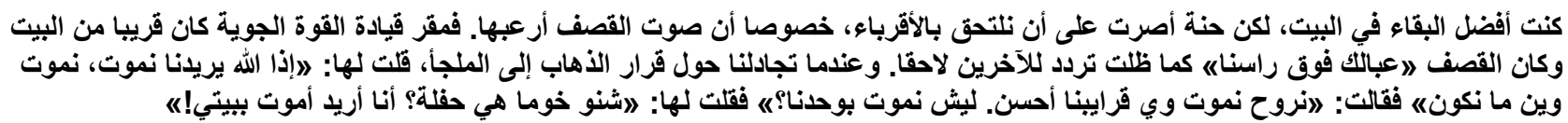

29

(ANTOON, 2012, p. 27)

كاتت أمهر القادمة حديثة نسبيا من القرية تخاطبهم وتخاطب زوجها بالكلدانية التي كانوا يفهمونها، لكنهم كانو ايجييون بالعربية.

(ANTOON, 2012, p. 42)

30 Primeiro Ministro Iraquiano, por três vezes (mar-nov. de 1933; mar-fev. de 1941; e abr-mai de 1941), era reconhecido por seu posicionamento nacionalista e insistência em remover a influência britânica que ainda operava no Iraque.

31

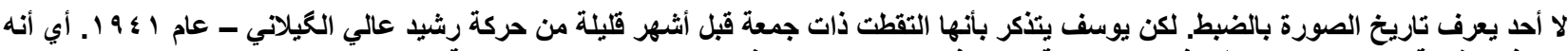

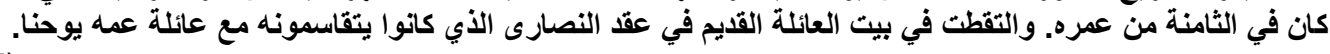

(ANTOON, 2012, p. 37) 
e ele cristão, isto era uma barreira social enorme que devia escalar"32 (ANTOON, 2012, p. 64-65).

Entretanto, os anos que se seguiram foram se tornando cada vez mais obscuros, não obstante encarassem com certa ironia; o conservadorismo que invadiu o Iraque na década de 1990 foi sentido por sua geração:

Depois da campanha religiosa que fechou os bares, no ano de 1994, passamos a nos encontrar nas casas. Um dia, gracejou Sa'dun dizendo: 'Filhos da puta, nos fizeram retornar aos dias de luta secreta, bebendo na clandestinidade. ${ }^{33}$ (ANTOON, 2012, p. 74).

Youssef e Sa'dun, embora sejam mais resilientes ao caos que assolou o país do que Maha, tentam de alguma forma entender o que levou o país a essa situação de calamidade, desespero e que, para a maior parcela da sociedade, parece irreversível:

Bem, quando a opinião pública mudar, nós já teremos morrido há muito tempo. Se é que ela vai mudar. O país se perdeu entre o Iran, os árabes e os americanos. Juro por Deus, não sei, quer dizer, esse sectarismo todo estava presente e nós não o percebemos entre nós? É possível? Onde estava escondido? Ou isso aconteceu recentemente, e está por trás das intervenções e do ódio que têm por nós, e aqueles que eram de dentro, mas na verdade eram de fora, e trouxeram com eles toda sua sujeira? Veja a Sundus aí na sua frente, ela não se casou com um chiíta? Isso era um problema há 15 anos? ${ }^{34}$ (ANTOON, 2012, p. 81)

Por fundamentar seus argumentos em fatos históricos nunca testemunhados pela jovem, Youssef é continuamente acusado pela sobrinha: "você vive no passado, tio" 35 (ANTOON, 2012, p. 9). É por causa dessa acusação, em uma das diversas discussões ocorridas entre os dois, que a caixa de memórias de Youssef é aberta, no início do romance, e nos encontramos em um Iraque totalmente diferente daquele conhecido por Maha e por nós, na contemporaneidade.

32

فقد كاتت تصغره بأكثر من عشرين سنة، ومن المستحيل أن تتجذب إلى رجئ رجل بعمر أبيها.

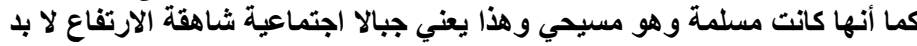

(ANTOON, 2012, p. 64-65)

33

بعد الحملة الإيمانية التي أغلقت فيها الحانات عام ؟9 9 أنتقلت الجلسات إلى البيوت. وتتدر سعدون يومها قائلا: لاخوات القحبة، رجعونا لأيام النضال

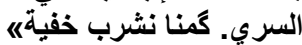

(ANTOON, 2012, p. 74)

34

》المن تنكئب العمايم إحنا يمكن نكون شابعين موت. هاي إذا انعلت. ضاع إع البلا بين إيران والعربان والأمريكان. والله ما أدري يعنى جانت كل هالطائفية

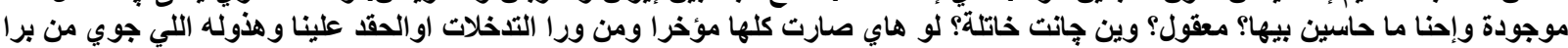

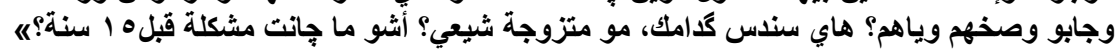

(ANTOON, 2012, p. 81)

اتت عيش بالماضي عمو!

(ANTOON, 2012, p. 9) 


\section{Os dilemas entre a memória e a história}

À luz da fala de Ginzburg (2006), que propõe uma reflexão sobre a política da memória e seus efeitos vertiginosos, pois desestabiliza imagens seguras e estáveis do passado, nos é revelada a espinha dorsal do romance de Antoon que, ao nos apresentar a história do Iraque através das memórias individuais de dois sujeitos de gerações diferentes, faz-nos entender a necessidade de se revisitar esse passado para se refletir sobre o presente.

A divergência nos pontos de vista de Maha e Youssef sobre questões políticas do presente e, consequentemente, seu posicionamento têm muita influência do que ambos viveram no passado e do que, para eles, se tornou memória. Aquilo que Youssef compartilha, ao revisitar seu passado, entra em confronto direto com o que Maha tem para se lembrar. São momentos históricos separados por poucas décadas, mas é tempo suficiente para revelar a duas pessoas realidades sociais e históricas completamente distintas.

É importante ter em mente que as experiências que, posteriormente, tornaram-se memórias, foram vividas em períodos históricos diferentes, portanto as narrativas das memórias desses sujeitos poderão ser antagônicas de acordo com os desdobramentos históricos no Iraque. Enquanto Youssef tem memórias cujas experiências são permeadas por momentos em família e entre amigos, num Iraque muito mais receptivo aos valores da modernidade, Maha as tem de dor, perda e medo, fruto de um acirramento dos movimentos conservadores de tradição islâmica, ditadura, guerras e emergência de milícias armadas. Duas experiências vividas em períodos diferentes que produzem perspectivas diferentes de um mesmo Iraque.

Se a memória, para Youssef, cumpre um papel na sua vida, qual seja, o de mantê-lo no presente, vivo, as lembranças de Maha corroem seus dias e impedem-na de viver. Tal dilema foi explorado por Nietzsche (2003) em seu manifesto contra o historicismo que se estabeleceu na Europa do século XIX, sobre a importância da memória para o indivíduo, povo ou cultura.

De acordo com o autor, o ser humano padece de um dilema: embora olhe para o animal consciente de sua superioridade, sofre ao ver naquilo que julga inferior a felicidade infinita da qual não pode gozar. Essa felicidade desfrutada pelo animal, segundo o filósofo, advém do fato de que ele não possui a paradoxal capacidade do 'lembrar-se' e construir memórias, capacidade humana que o singulariza enquanto sujeito.

O caráter paradoxal do "lembrar-se" repousa no fato de que, ao mesmo tempo que é gloriosa a memória, a incapacidade do 'esquecer-se', que é a garantia da felicidade infinita do animal, torna-se o fardo que o sujeito tem que carregar, pois estas memórias estão calcadas na sua subjetividade.

Se o "lembrar-se" constrói a subjetividade do ser humano e, de algum modo, é nossa garantia de que estamos vivos, "a existência é apenas um ininterrupto ter sido, uma coisa de se negar e de se consumir, de se autocontradizer" (NIETZSCHE, 2003, p. 8), pois tudo aquilo que "é", num átimo passa ao "foi", de modo que a existência humana seria 
"imperfectum que nunca pode ser acabado" (NIETZSCHE, p. 8-9, grifo no original). Nesse sentido, a morte seria "o ansiado esquecer, então ela extingue ao mesmo tempo o presente e a existência [...]" (NIETZSCHE, p. 8). Youssef, então, se agarraria às memórias para não morrer. Continuar lembrando-se é manter-se vivo.

Embora a memória seja aquilo que constitui a nossa subjetividade, a felicidade reside no "esquecer-se", - ou na faculdade de sentir-se a-historicamente -, pois "é possível viver sem lembrança, sim, e viver feliz assim, como mostra o animal; mas é absolutamente impossível viver, em geral, sem esquecimento" (NIETZSCHE, p. 10).

Nietzsche (2003) defende que há um grau de estado de consciência ininterrupto de sentido histórico vivido que é capaz de degradar e sucumbir um homem ou, até mesmo, um povo e sua cultura. Esse grau é determinado pela capacidade de perceber o que precisa ser esquecido, para não se enterrar o presente, e essa percepção é tomada pelo tamanho da força plástica, de um homem, um povo e sua cultura. Essa força de transferência e incorporação do que é estranho e passado, curando feridas, restabelecendo o perdido, seria uma força regenerativa, tal qual a resiliência do sujeito ou de uma nação.

Nessa perspectiva, um sujeito ou um povo saudável deveria, instintivamente, saber reconhecer os momentos de se pensar histórica e a-historicamente:

Como a história poderia servir melhor à vida, a não ser se conectasse as gerações e as populações menos favorecidas à sua terra natal e aos hábitos de sua terra natal, enraizando-as e impedindo-as de vaguear por aí em busca do que é melhor no estrangeiro e de se engajar em uma luta ferrenha por ele? (NIETZSCHE, 2003, p. 27-28).

A despeito de todas as mazelas da história iraquiana, a identidade de Youssef e suas raízes o sustêm. Dentro da perspectiva nietzschiana, o personagem nos apresenta um sujeito cuja força plástica sustenta o peso de seu passado marcado pelos desdobramentos históricos de seu país cujas consequências atingiram diretamente sua individualidade: o fechamento dos pubs que causou a desintegração de seu clube, a perseguição aos cristãos assírios e a necessidade de frequentar o templo da comunidade armênia, o desterro de seus familiares e sua imigração, a solidão imposta pelo desintegração da sociedade. Mesmo diante de todas essas intempéries, Youssef se mantém firme, enraizado como as tamareiras que ainda se erguem nos jardins das casas de Bagdá: "[...] eu sabia e sempre repetia que a situação das tamareiras não difere da dos humanos"36 (ANTOON, 2012, p. 84).

Comparando a tamareira com a casa, Youssef eleva a casa à vida. Por isso, ele não pode emigrar. A maneira como o reconhece e o valor atribuído ao seu espaço impedem-no de deixar o Iraque:

Olhei as folhas das duas tamareiras de casa de longe erguidas no jardim

36

كنت أعرف وأردد دائما بأن أحوال النخل لا تختلف عن أحوال البشر [...]

(ANTOON, 2012, p. 84) 
dos fundos e pareciam guardar a casa. Eu também guardo a casa e suas memórias. A casa é mais que uma casa. Do mesmo modo que a tamareira não é puramente uma tamareira, mas uma vida em sua perfeição. Enraizada no solo sob ela e em tudo que há nele, estabelecida sob o céu que se estende e o ar que respira e tudo o que há nele. Pois a casa também não é puramente pisos, cimento e pintura, mas uma vida inteira. ${ }^{37}$ (ANTOON, 2012, p. 85)

Youssef é um guardador de memórias, um antiquário, cujo caráter revela, como propôs Nietzsche (2003, p. 27):

[...] o contentamento da árvore com as suas raízes, a felicidade de não se saber totalmente arbitrário e casual, mas de crescer a partir de um passado como a sua herança, o seu florescimento e fruto, sendo através daí desculpado, sim, mesmo justificado em sua existência - é isto que se designa agora propriamente como o sentido histórico apropriado.

Embora se mantivesse firme, Youssef, assim como as tamareiras de Bagdá, é morto. Vítima de forças alheias, ele é arrancado da terra e com ele se vai o testemunho e as memórias daquilo que um dia foi o Iraque que Maha nunca conheceu. Nas mãos de Maha, representado nas câmeras da emissora, o mundo vê Youssef, ouve o que a jovem testemunhou no atentado terrorista que matou seu tio, mas não ouve e nada sabe sobre o que já "foi". Entretanto, nós, pela narrativa de Antoon, sabemos.

\section{Eucaristia}

Enquanto oram pela paz no Iraque e pela composição de um governo que priorize a paz e o bem-estar no país, a igreja de Youssef é atacada, os fiéis todos mortos. Só Maha permanece viva, não porque é poupada, mas é refém. Nas mãos dos terroristas, a jovem acompanha a negociação entre os terroristas e uma rede de televisão, esperando a morte. Lembra-se do tio também presente na missa. Lembra-se que não teve tempo de lhe pedir perdão pela última discussão que tiveram, há dois dias, quando lhe acusou de viver no passado. Era tarde demais.

Antes que igreja seja invadida pelo corpo antiterrorista e Maha seja salva, o narrador, descrevendo o grupo que ataca o local, nos dá pistas do que está surgindo no país e que, em pouco tempo, passará a ser parte da mídia internacional: o Estado Islâmico.

Diante de tudo que experienciou, Maha entende que tem uma missão. Com a fotografia do tio, morto no massacre, decide dar uma entrevista televisiva, pois "queria que o mundo todo soubesse a verdade sobre o que aconteceu" (ANTOON, 2012, p. 149).

Embora tenha que sempre lembrar sua comunidade leitora de que os personagens

37

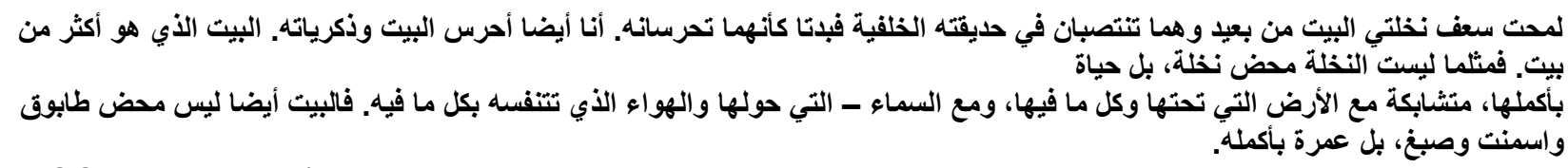

(ANTOON, 2012, p. 85) 
desse texto são fictícios, a universalidade e maestria do trabalho de Antoon reside no fato de que, em qualquer uma das esquinas de Bagdá, vive uma Maha pertencente a uma família Jurji.

Seu texto introduz o leitor em uma realidade de violências distintas: recorrentes conflitos sectários, políticas de regimes ditatoriais, morte de entes da família, perda da infância, a morte do não nascido, o desterro, ser estrangeiro na própria pátria e intolerância religiosa.

Personagens que não estão claramente representando um posicionamento político, mas que são vítimas de decisões ideológicas tomadas no plano político de uma nação. Histórias pessoais silenciadas que, se alinhavadas, nos colocam na esteira dos acontecimentos políticos do Iraque das últimas décadas.

Ao nos propor as diferentes justificativas para a origem da época de ouro do país, são abertas possibilidades interpretativas, sobretudo para se questionar se esse tempo realmente existiu, ou para pensarmos que as coisas sempre foram conflituosas em alguma medida para grupos sociais diferentes, o que explicaria, em alguma medida, a divergência e a ilusão sobre um tempo áureo. Basta vermos que a história moderna do estado iraquiano aponta para essa instabilidade partilhada por toda a região do Oriente Médio. Desde a fragmentação do Império Otomano, a presença britânica, o esfacelamento da monarquia, a ditadura, a ocupação americana e o domínio do Estado Islâmico.

Revisitar as memórias de Maha e Youssef, mesmo que no texto ficcional, nos revela fatos sobre a história iraquiana de algum período em que se gozava de certa estabilidade na relação entre cristãos, muçulmanos e outras minorias, mas, pouco tempo depois, há uma mudança drástica no rumo da situação. Cristãos foram expulsos de suas casas, sofreram atentados em igrejas, chamados de infiéis e mandados embora do país. $O$ desfecho da fala de Maha pode ser seguido pelos relatos que nos foram transmitidos pela mídia internacional há pouco tempo sobre a situação do Iraque: controle do país pelo Estado Islâmico, massacre de minorias, desterro, destruição da memória histórica da humanidade representada pelos museus e sítios arqueológicos e a perda da esperança de que o país ressurgirá da morte de novo para vida.

\section{Referências}

AL-MUSAWI, Muhsin Jassim. Postcolonial Matters in Arabic Narrative. In: AL-MUSAWI, Muhsin Jassim. The postcolonial Arabic novel: debating ambivalence. Leiden: Brill, 2003, p. 21-61.

ANTOON, Sinan. Ya Maryam. Beirute/Bagdá: Dar al-Jamal, 2012.

BAHOORA, Haytham. Iraq. In: HASSAN, Waïl S. (Ed.). The Oxford Handbook of Arab Novelistic Traditions. New York: Oxford University Press, 2017, p. 247-264. Disponível em: https://www.oxfordhandbooks.com/view/10.1093/oxfordhb/9780199349791.001.0001/oxfor dhb-9780199349791-e-16. Acesso em: 16 fev. 2021. 
GINZBURG, Jaime. Política da memória no Brasil: raça e história em Oliveira Vianna e Gilberto Freyre. Araucária, v. 8, n. 15, p. 36-45, abr. 2006.

NIETZSCHE, Friedrich. Segunda Consideração Intempestiva. Da utilidade e desvantagem da história para a vida. Trad. de Marco Antônio Casanova. Rio de Janeiro: Relume Dumará, 2003.

\section{NOTAS DE AUTORIA}

Jemima de Souza Alves (jemima.alves@usp.br) é Doutoranda do Programa de Pós-Graduação Letra FFLCH da Universidade de São Paulo, pesquisa tradução de literatura árabe contemporânea, é bolsista do CNPQ. Mestre em Letras pelo Programa de Estudos Judaicos e Árabes, com bolsa de estudos da CAPES, na mesma instituição.

\section{Agradecimentos}

Não se aplica

Como citar esse artigo de acordo com as normas da ABNT

ALVES, Jemima de Souza. Os dilemas entre a memória e a história em Ya Maryam, um romance de Sinan Antoon. Anuário de Literatura, Florianópolis, v. 26, p. 01-17, 2021.

\section{Contribuição de autoria}

Não se aplica.

\section{Financiamento}

Conselho Nacional de Desenvolvimento Científico e Tecnológico - CNPq.

\section{Consentimento de uso de imagem}

Não se aplica.

\section{Aprovação de comitê de ética em pesquisa}

Não se aplica.

\section{Conflito de interesses}

Não se aplica.

\section{Licença de uso}

Os/as autores/as cedem à Revista Anuário de Literatura os direitos exclusivos de primeira publicação, com o trabalho simultaneamente licenciado sob a Licença Creative Commons Attribution (CC BY) 4.0 International. Estra licença permite que terceiros remixem, adaptem e criem a partir do trabalho publicado, atribuindo o devido crédito de autoria e publicação inicial neste periódico. Os autores têm autorização para assumir contratos adicionais separadamente, para distribuição não exclusiva da versão do trabalho publicada neste periódico (ex.: publicar em repositório institucional, em site pessoal, publicar uma tradução, ou como capítulo de livro), com reconhecimento de autoria e publicação inicial neste periódico.

\section{Publisher}

Universidade Federal de Santa Catarina. Programa de Pós-graduação em Literatura. Publicação no Portal de Periódicos UFSC. As ideias expressadas neste artigo são de responsabilidade de seus/suas autores/as, não representando, necessariamente, a opinião dos/as editores/as ou da universidade.

\section{Histórico}

Recebido em: 31/10/2020

Aprovado em: 25/01/2021

Publicado em: 28/06/2021 